\title{
CONSTITUCIÓN Y RELACIONES PATERNO-FILIALES: ALGUNOS APUNTES * $^{*}$
}

\author{
THE CONSTITUTION AND PARENT-CHILD RELATIONSHIPS: SOME \\ NOTES
}

\author{
Alicia GonZÁlez Alonso**
}

\begin{abstract}
Resumen: El presente trabajo tiene por objeto analizar el marco constitucional regulador de las relaciones paterno-filiales en los casos de minoría de edad de los hijos. Los derechos fundamentales, así como los mandatos de protección de los menores de edad por parte de los responsables parentales y de los poderes públicos contenidos en el artículo 39 de la Constitución conforman ese espacio normativo que actúa como límite no solo frente a la autonomía de la voluntad de los concernidos en dicha relación, sino también frente al legislador y el resto de los poderes públicos. Palabras clave: Relaciones paterno-filiales, ejercicio de los derechos fundamentales por los menores de edad, deberes de protección hacia los menores de edad.
\end{abstract}

Abstract: The purpose of this paper is to analyse the constitutional regulatory framework of parent-child relationships in cases of children who are minors. The fundamental rights, as well as the child protection mandates by the parents responsible and the public authorities contained in article 39 of the Constitution, make up the regulatory area that acts as a limit when faced with, not only to the autonomy of the will of those concerned in said relationship, but also before the legislator and the rest of the public powers.

Keywords: Parental relations, exercise of fundamental rights by minors, duties of protection towards minors.

SUMARIO: I. CONSTITUCIÓN, RELACIONES PATERNO-FILIALES Y AUTONOMÍA DE LA VOLUNTAD; 1. La persona y la minoría de edad: criterios determinantes de la regulación constitucional de las relaciones paterno-filiales; 2 . Constitución, ley y autonomía de la voluntad en las relaciones paterno-filiales; II. EL MARCO REGULADOR DEL ART. 39 CE; 1. Las disposiciones del artículo $39 \mathrm{CE}$ : ¿principios rectores, deberes constitucionales o derechos subjetivos?; 2. El artículo 39 CE. III. DERECHOS FUNDAMENTALES Y RELACIONES PATERNO-FILIALES; 1 . ¿Son titulares de derechos fundamentales los menores de edad?; 2.

* http://doi.org/10.15366/rjuam2018.38.007

Fecha de recepción: 18 de noviembre de 2018.

Fecha de publicación: 19 de diciembre de 2018.

** Profesora Contratada Doctora de Derecho Constitucional. Universidad Autónoma de Madrid. Correo electrónico: alicia.gonzalez@uam.es. Este trabajo se enmarca en el Proyecto de Cooperación Interuniversitaria UAM-SANTANDER con América Latina 2017-2018 «La libertad de autodeterminación en las relaciones familiares y sus límites como desafío del Derecho de Familia del siglo XXI en España y América Latina». 
El carácter permanentemente controvertido del ejercicio de los derechos fundamentales por los menores de edad: una nueva vuelta de tuerca tras la reforma de 2015; 3. La patria potestad como criterio modulador del ejercicio de los derechos fundamentales de los responsables parentales; IV. BIBLIOGRAFÍA.

\section{CONSTITUCIÓN, RELACIONES PATERNO-FILIALES Y AUTONOMÍA DE LA VOLUNTAD}

\section{La persona y la minoría de edad: criterios determinantes de la regulación constitucional de las relaciones paterno-filiales}

La aprobación de la Constitución de 1978 no solo ha supuesto la transformación radical de las relaciones entre el individuo y el poder público, sino que también ha afectado de manera decisiva a las relaciones familiares y, dentro de estas, a las paterno-filiales. En efecto, desde hace ya varias décadas ha quedado superado no solo el modelo tradicional de familia, sino también la forma en que se venía ejerciendo la patria potestad, basada en relaciones de poder en las que el padre de familia ocupaba un lugar central en esta. Es evidente que el cambio al que se acaba de hacer referencia ha sido consecuencia de un largo proceso en el que han intervenido múltiples factores, sobre todo de tipo económico y social, que el Derecho -nacional e internacional- ha acogido, dando lugar en los últimos años a una progresiva «publificación» de la familia y, en consecuencia, también de las relaciones paterno-filiales. La afirmación de nuestro Estado en el art. 1.1 CE como social y democrático de Derecho, el reconocimiento de los derechos fundamentales de los ciudadanos y la necesidad de protección de la familia y de los menores de edad (art. $39 \mathrm{CE}$ ), son los pilares sobre los que se asienta este nuevo Derecho de familia que surge tras la aprobación de la Constitución de $1978^{1}$.

Son dos, en mi opinión, las notas esenciales que cabe derivar de la Constitución y que impregnan y tiñen todo los que se dirá más adelante en relación con el asunto del que me ocupo; esto es, las relaciones paterno-filiales: la persona como titular de derechos fundamentales y la necesidad de protección que requieren los hijos y, en especial, los menores de edad.

Por lo que se refiere a la primera de las cuestiones apuntadas, hay que subrayar que el proceso que se ha experimentado en torno a las relaciones familiares puede resumirse en la expresión de Roca Trías $^{2}$ «de la casa a la persona». Y es que, el Derecho y más concretamente la Norma Fundamental, mediante el reconocimiento de los derechos fundamentales, sitúa a la persona en el centro del sistema de tal manera que los derechos e intereses de estas no pueden quedar anulados por el grupo al que pertenecen, en este caso, por la familia o

Vid., en este sentido, ROCA TRÍAS, E., Familia y cambio social (de la «casa» a la persona), Madrid (Cuadernos Civitas),1999, pp. 67-68.

2 ROCA TRÍAS, E. Familia y cambio social (de la «casa» a la persona), cit. 
por algunos de sus miembros. En este sentido y siguiendo a Aguado Renedo, el mandato constitucional de protección por parte de los poderes públicos a la familia (art. $39 \mathrm{CE}$ ) no puede ser entendido sino como un plus para los componentes que forman parte de esta, no como una habilitación que trata de jerarquizar los intereses de la familia sobre los del individuo ${ }^{3}$. O, como ha puesto de relieve Roca Trías, la familia no tiene un reconocimiento distinto o superior del que se atribuye a sus miembros, de tal manera que debe ser entendida no como un fin en sí mismo, sino como un instrumento al servicio de sus componentes ${ }^{4}$. En efecto, así debe considerarse a partir de la doctrina general de los derechos fundamentales en la medida en que el reconocimiento de algunos de estos a las personas jurídicas tiene como finalidad facilitar y maximizar las cotas de libertad del propio individuo o, incluso, permitirle ejercer determinados derechos fundamentales de forma colectiva, pero no supeditar los derechos del individuo a los del grupo en el que este se inserta ${ }^{5}$. La garantía de los derechos fundamentales y la prohibición de discriminación por razón de sexo también ha cambiado la forma en la que se ejerce la patria potestad ya que hemos pasado de un sistema en el que el padre ocupaba una posición de primacía no solo sobre los hijos, sino también sobre la madre.

Por lo que se refiere a la segunda de las notas apuntadas, la necesidad de limitar la autonomía de la voluntad por la intervención del poder público es mucho más intensa en las relaciones paterno-filiales cuando los hijos son menores de edad que en relación con las que tienen lugar entre adultos, por ejemplo, entre los esposos o miembros de la pareja o con los hijos mayores de edad ${ }^{6}$. El régimen constitucional aplicable al primero de los supuestos apuntados atiende, más que a razones de parentesco, a una cuestión circunstancial cual es la minoría de edad de los hijos y al interés público en que estos sean objeto de una protección integral. Por ello el art. 39.3 CE establece el deber de los padres «de prestar asistencia de todo orden a los hijos [...] durante su minoría de edad», remitiéndose en los demás casos «a lo que la ley establezca» ${ }^{7}$. El plano de la constitucionalidad y de la legalidad quedan delimitados en este caso en atención a si los hijos son mayores o menores de edad. Según el TC «el estatuto del menor es, sin duda, una norma de orden público, de inexcusable observancia para todos los poderes públicos» (STC 141/2000) en el que el interés superior del menor, al que el ordenamiento y la jurisprudencia viene atribuyendo progresivamente un papel fundamental en las últimas décadas, debe quedar siempre salvaguardado.

3 AGUADO RENEDO, C., «Familia, matrimonio y Constitución Española», en DÍEZ-PICAZO GIMÉNEZ, G. (coord.), Derecho de Familia, Cizur Menor (Thomson Reuters-Civitas), 2012, p. 83.

4 ROCA TRÍAS, E., Familia y cambio social (De la «casa» a la persona), cit., p. 70.

5 GÓMEZ MONTORO, A.J., «Titularidad de Derechos Fundamentales», en ARAGÓN REYES, M. (dir.), Derechos Fundamentales y su protección. Temas básicos de Derecho Constitucional, T. III, Cizur Menor (Civitas), 2011, p. 53.

6 No debe deducirse de lo expuesto en el texto principal que los derechos y deberes en las relaciones paterno-filiales se extinguen una vez alcanzada la mayoría de edad. El CC está plagado de disposiciones que imponen obligaciones no solo entre padres e hijos mayores de edad, sino también entre parientes, lo que se justifica sobre la base del principio de solidaridad que rige en este ámbito.

7 La cursiva es añadida. 


\section{Constitución, ley y autonomía de la voluntad en las relaciones paterno-filiales}

Partiendo de los presupuestos expuestos hasta ahora, no hay que entender las relaciones paterno-filiales como algo estrictamente privado, en el que el Estado no debe inmiscuirse o hacerlo solo en los supuestos en los que exista un riesgo importante para la vida o la integridad física de las personas que forman parte de esta y, en especial, de los menores de edad. A pesar de ello, desde determinados postulados y con base en el derecho a la intimidad familiar y a la autonomía de la voluntad, se apuesta por situar a la familia como un ámbito inmune a la acción del Estado.

Sin embargo, no es esto lo cabe derivar del texto constitucional. Las normas constitucionales que inciden de forma decisiva en este marco regulador y que ponen de relieve el interés predominante al que sirven que, como se verá, son de carácter público, son los derechos fundamentales previstos en el Capítulo II del Título Primero de la Constitución $\mathrm{y}$, muy especialmente, los mandatos de protección, los deberes y derechos subjetivos que se regulan en el art. $39 \mathrm{CE}$, entramado normativo este que impide considerar las relaciones paterno-filiales como un asunto eminentemente privado o ajeno a la intervención del Estado.

Es más, en la actualidad, apelar a ese orden constitucional sin tener en cuenta las exigencias que se derivan de lo que se ha venido denominando la tutela multinivel de los derechos fundamentales no parece posible. En el caso español, además de la cláusula de apertura contenida en el art. 10.2 CE, se establece en el art. 39.4 CE respecto de los niños -con independencia de que pertenezcan o no a una familia- que gozarán de la protección prevista en los acuerdos internacionales que velan por sus derechos; esto es, es la propia Constitución la que incorpora como derecho propio los derechos de los niños contenidos en las normas internacionales ${ }^{8}$. Así, el orden público constitucional, según ha declarado el $\mathrm{TC}^{9}$, queda integrado no solo por la normativa interna sino también por la Convención de

8 Según señala DÍAZ CREGO, M., «Artículo 39» en PÉREZ TREMPS, P. y SÁINZ ARNÁIZ, A. (dirs.), Comentario a la Constitución Española. Libro-Homenaje a Luis López Guerra. 40 Aniversario 1978-2018, Valencia (Tirant lo Blanch), 2018, p. 790. El principal problema interpretativo que genera este precepto es determinar si esta remisión solo debe abarcar los acuerdos internacionales suscritos por el Reino de España o si, por el contrario, podrían también tener algún grado de eficacia acuerdos internacionales no suscritos por el Estado.

9 El TC ha hecho referencia expresa a esta noción de «orden público» del que forman parte los Tratados internacionales referidos. Así, en la STC 141/2000 establece:

«tratándose, como se trata en el caso de autos, de la supuesta afectación de dos menores de edad por las prácticas de su padre de conformidad con sus creencias, no deben dejar de ser tenidas en cuenta las normas internacionales de protección de la infancia, que son de aplicación en España. Y, entre ellas, muy en particular, la Convención de la Naciones Unidas sobre los Derechos del Niño (ratificada por España por Instrumento de 30 de noviembre de 1990) y la Resolución del Parlamento Europeo relativa a la Carta Europea de los Derechos del Niño (Resolución A 3-0172/92 de 8 de julio), que conforman junto con la Ley Orgánica 1/1996, de 15 de enero, de Protección Jurídica del Menor, vigente al tiempo de la Sentencia de apelación, el estatuto jurídico indisponible de los menores de edad dentro del territorio nacional, en desarrollo de lo dispuesto en el art. 39 CE, y muy en particular, en su apartado 4. A estos 
la Naciones Unidas sobre los Derechos del Niño (en adelante, CDN), la Resolución del Parlamento Europeo relativa a la Carta Europea de los Derechos del Niño, aprobada el 8 de julio de 1992 (SSTC 141/2000, 152/2005 y 29/2017), entre otras. Desde una perspectiva más amplia y no circunscrita a los derechos de los niños, hay que insistir en la importancia que han tenido en este sentido los pronunciamientos del TEDH en orden clarificar las obligaciones del Estado que se derivan del Convenio Europeo de Derechos Humanos en torno al tema que nos ocupa. Aunque más adelante volveré sobre este asunto, es preciso poner de relieve que el derecho a la intimidad familiar reconocido en el art. 18.1 CE contempla un haz de facultades muy limitado en comparación con el contenido protegido del art. 8.1 CEDH que garantiza el derecho a la vida familiar. Sin embargo, esto no ha impedido que el TC haya tomado en consideración la doctrina del TEDH y la haya conectado con el art. $39 \mathrm{CE}$ en relación con algunos derechos amparables como el art. 18.1 CE en la medida en que garantiza la intimidad no solo personal sino también familiar.

Este entramado de derechos fundamentales, principios y mandatos de protección; en definitiva, el conjunto de normas que conforman el orden público constitucional en esta materia actúa como límite y a su vez como garantía, dejando un amplio margen de maniobra al legislador. En efecto, la Constitución es lo que no se vota, lo que se sustrae a la mayoría parlamentaria, por lo que existe, también en esta materia, un amplio margen de libertad de configuración por parte del legislador que debe desenvolverse dentro del marco constitucional ${ }^{10}$. Como ha declarado el TC en diversas ocasiones (por todas STC 11/1981) «la Constitución es un marco de coincidencias suficientemente amplio como para que dentro de él quepan opciones políticas de muy diferente signo», por lo que no es posible tener por agotada la materia atendiendo exclusivamente al texto constitucional. Muy al contrario, el espacio para el legislador es grueso por la amplitud de las materias a las que se refiere y al alto grado de indeterminación de algunas de estas: los derechos fundamentales de las personas, no solo entendidos como derechos subjetivos sino también en su vertiente objetiva como elementos esenciales y basilares del ordenamiento jurídico, así como los derechos subjetivos, deberes constitucionales y principios rectores que se contienen en el art. $39 \mathrm{CE}$. A propósito de este último precepto, el TC ha tenido la oportunidad de subrayar en varias ocasiones que no cabe derivar del mismo que la protección a la familia haya de llevarse a cabo a través de la adopción de unas medidas determinadas (STC 214/1994) ${ }^{11}$. Por ello, la autonomía de la voluntad en este campo puede ser limitada desde una doble perspectiva, por un lado, por la Constitución y, por otro, por el legislador a la hora de regular la materia en atención a las mayorías parlamentarias que se vayan conformando a lo largo del tiempo.

efectos, el estatuto del menor es, sin duda, una norma de orden público, de inexcusable observancia para todos los poderes públicos, que constituye un legítimo límite a la libertad de manifestación de las propias creencias mediante su exposición a terceros, incluso de sus progenitores». La cursiva es añadida.

10 ZAGREBELSKY, G., Principios y votos. El Tribunal Constitucional y la política, trad. Martínez Neira, M., Madrid (Trotta), 2008.

11 Vid. en este sentido, DÍAZ CREGO, M., «Artículo 39», cit., p. 784. 
De lo que se trata en las siguientes páginas es de intentar exponer o aproximarnos al orden público constitucional que actúa como límite -y a su vez garantía- de los bienes y derechos dignos de protección en las relaciones paterno-filiales -en sí mismas consideradas y en su ordenación y limitación por parte del legislador- $-\mathrm{y}$ que quedan conformados por las normas antes aludidas.

\section{EL MARCO REGULADOR DEL ARTÍCULO 39 CE}

Las relaciones paterno-filiales pueden verse afectadas por lo dispuesto en los distintos apartados del art. 39 CE. Así, dicho precepto establece un mandato de protección a la familia a cargo de los poderes públicos (art. 39.1 CE), que se predica con el calificativo de «integral» respecto de los hijos, «iguales estos ante la ley con independencia de su filiación», siendo una manifestación de esta la investigación de la paternidad (art. 39.2 CE); determina, asimismo, la asistencia «de todo orden» que los padres deben prestar a los hijos, habidos dentro o fuera del matrimonio, durante la minoría de edad «y en los demás casos que legalmente proceda» (art. 39.3 CE); y finaliza estableciendo que «los niños gozarán de la protección prevista en los acuerdos internacionales que velan por sus derechos» (art. 39.4 CE).

\section{Las disposiciones del artículo 39: ¿principios rectores, deberes constitucionales o derechos subjetivos?}

El art. 39 está ubicado en el Capítulo III, del Título I de la CE, en el que se contienen los principios rectores de la política social y económica cuya eficacia y grado de vinculación a los poderes públicos se regulan en el art. 53.3 CE. Sin embargo, dada la forma en la que están enunciadas algunas disposiciones del art. $39 \mathrm{CE}$, cabe preguntarse si constituyen principios rectores $\mathrm{o}$, en realidad, confieren derechos subjetivos que limitan la actuación del legislador. Tal y como ha señalado un sector doctrinal, en el Capítulo III del Título I de la Constitución no solo hay principios rectores sino también verdaderos derechos subjetivos que, bien en relación con otros derechos fundamentales como el art. $14 \mathrm{CE}$, o bien por sí mismos, constriñen la libertad del legislador ${ }^{12}$. Sin duda, tal es lo que acontece con la declarada igualdad de los hijos con independencia de su filiación y de las madres al margen de su estado civil, así como con la afirmación de que la «ley posibilitará la investigación de la paternidad».

Por lo que se refiere al primero de los derechos apuntados, esto es, a la igualdad de los hijos con independencia de su filiación, se trata de manifestaciones o concreciones del art. $14 \mathrm{CE}$ que garantiza el principio de igualdad y la prohibición de discriminación, entre

\footnotetext{
12 Coincido plenamente en este punto con AGUADO RENEDO, C., «Familia, matrimonio y Constitución española», cit., p. 81 .
} 
otras, por razón de nacimiento ${ }^{13}$. Probablemente, la intención del constituyente al incluir expresamente la prohibición de discriminación por razón de nacimiento fue romper de una vez por todas con la situación de desventaja, promovida tanto por los poderes públicos como por la propia sociedad -incluyendo incluso al propio progenitor-, que históricamente han tenido los hijos extramatrimoniales con los habidos dentro del matrimonio ${ }^{14}$. Pero el alcance del precepto no debe limitarse a estos casos, sino a cualesquiera otros derivados del nacimiento. De esta manera, la Constitución equipara hijos matrimoniales y no matrimoniales, por un lado, e hijos naturales y adoptados por otro; equiparación esta que trajo consigo una profunda modificación de la legislación en materia de filiación ${ }^{15}$, aunque requirió también la intervención del TC en los primeros años de su puesta en funcionamiento. Efectivamente, en una de las primeras resoluciones del TC en las que el Alto Tribunal incide en el carácter normativo de la Constitución y en la eficacia directa de los derechos fundamentales, en este caso el art. $14 \mathrm{CE}$, se refiere a un supuesto de desigualdad de hijos matrimoniales y extramatrimoniales (STC 80/1982).

Bajo el examen también del art. 14 CE, y ya en los albores del nuevo siglo, el TC ha tenido que pronunciarse sobre la equiparación entre hijos biológicos y adoptivos. Tras la estimación del amparo resuelto en la STC 46/1999 y, planteándose auto cuestión de inconstitucionalidad (art. 55.2 LOTC), declaró la incompatibilidad de una norma con rango de ley con la Constitución que establecía diferencias injustificadas entre hijos naturales y adoptivos (STC 200/2001) ${ }^{16}$. Hay que poner de relieve, no obstante, que en estos casos el parámetro de control tomado en consideración por el TC ha sido el art. $14 \mathrm{CE}$, refiriéndose al art. 39 como principio rector. No obstante, en resoluciones posteriores, entre otras en las SSTC 154/2006 y 9/2010, el TC, atendiendo al principio de interpretación sistemática, consecuencia del principio de unidad de la Constitución, ha afirmado que el art. $14 \mathrm{CE}$ opera en estos casos con el trasfondo del art. 39.2 y $3 \mathrm{CE}$, que obliga a los poderes públicos a asegurar «la protección integral de los hijos, iguales éstos ante la Ley con independencia

13 Así lo ha entendido también el TC al establecer que el art. 39 CE, «refleja una conexión directa con el art. 14 CE» (STC 154/2006).

14 Téngase en cuenta, a mayor abundamiento, que en nuestra Constitución las instituciones del matrimonio (art. 32 CE) y la familia (art. 39 CE) se regulan en preceptos separados. Sobre las consecuencias que se derivan de tal decisión del constituyente puede verse, RODRÍGUEZ RUIZ, B., «Matrimonio, género y familia en la Constitución española: trascendiendo la familia nuclear», Revista Española de Derecho Constitucional, vol. 91, 2011.

15 Vid. sobre la profunda transformación en esta materia, GREGORACI FERNÁNDEZ, B. «La filiación», en DÍEZ-PICAZO GIMÉNEZ, G. (coord.), Derecho de Familia, Cizur Menor (Thomson Reuters-Civitas), 2012, pp. 1607-1664.

16 Con el fin de evitar supuestos fraudulentos, el art. 41.2 del texto refundido de la Ley de Clases Pasivas del Estado aprobado por Real Decreto Legislativo 670/1987, de 30 de abril, condicionaba el cobro de la pensión de orfandad de los hijos adoptivos (no de los biológicos) a que el adoptante hubiera sobrevivido al menos dos años desde la fecha de la adopción. Dicha diferenciación entre hijos biológicos y adoptivos no logró superar el test de proporcionalidad. Aunque en dicho pronunciamiento el TC toma como parámetro principal de control de constitucionalidad el art. $14 \mathrm{CE}$, acaba señalando que en este caso concreto el legislador «está desconociendo la exigencia constitucional de dar protección a la familia y a los hijos (art. 39.1 y $2 \mathrm{CE}$ )». 
de su filiación» (STC 7/1994, de 17 de enero, FJ 3.b), y a los padres a «prestar asistencia de todo orden a los hijos habidos dentro o fuera del matrimonio», de manera que toda opción legislativa de protección de los hijos que quebrante por sus contenidos esa unidad en una discriminación por razón de nacimiento expresamente prohibida por el art. $14 \mathrm{CE}$, ya que la filiación no admite categorías jurídicas intermedias (STC 154/2006) ${ }^{17}$.

La rigurosa aplicación por parte del TC de la equiparación de las distintas formas de filiación ha llevado a que se haya apreciado la inconstitucionalidad en aquellos casos en los que se producía una discriminación indirecta, es decir, aquella que, bajo apariencia de tratamientos formalmente neutros, genera efectos adversos en determinados colectivos y, entre ellos, a los hijos habidos fuera del matrimonio ${ }^{18}$. Tal es lo que acontece en el caso resuelto por la STC 154/2006 en el que se impone una interpretación en sentido constitucional de la ley, corrigiendo la que habían venido manteniendo hasta la fecha los órganos judiciales ordinarios. Y es que, en efecto, la doctrina del TC referida a la prohibición de discriminación por nacimiento no solo vincula al legislador en los términos antes referidos, sino que también opera frente a los órganos judiciales en el desarrollo de la función jurisdiccional. Así, también los jueces, a la hora de interpretar el Derecho, quedan vinculados por estos derechos subjetivos. Con base en esta vinculación a los órganos del Poder Judicial, entre otras, en la STC 9/2010, se consideró contraria a la prohibición de discriminación la interpretación judicial de un testamento en el que la expresión «hijos legítimos» supuso excluir del mismo a dos nietas adoptivas con el argumento de que salvaguardar la autonomía de la voluntad del testador teniendo en cuenta los principios imperantes en el momento en que otorgó el testamento no debía considerarse contrario al art. 14 CE.

En definitiva, lo que interesa poner de manifiesto es que este precepto, en conexión con el art. $14 \mathrm{CE}$, genera límites a todos los poderes públicos, también al legislador, de tal manera que toda opción legislativa de protección de los hijos; es decir, dictada como consecuencia de lo previsto en el art. 39.2 CE que quebrante por sus contenidos la parificación

17 A la hora de fijar el parámetro de control de constitucionalidad de las resoluciones administrativas y judiciales impugnadas en el recurso de amparo resuelto por la STC 154/2006, el TC advierte que, aunque los arts. 41 y 39,2 CE no constituyen preceptos amparables «también es preciso advertir que el mantenimiento del régimen público de Seguridad Social (art. $41 \mathrm{CE}$ ), lo mismo que la protección integral de los hijos con independencia de su filiación (art. 39.2 CE), se contienen en el título I del Texto Constitucional, lo que permite establecer una directa relación entre ellos y el derecho fundamental invocado (art. 14 CE) [...], deduciéndose en su consideración conjunta un derecho de los hijos a beneficiarse de las prestaciones de Seguridad Social fijadas por las normas correspondientes sin discriminación por su filiación. Esa razón conecta e integra las alegaciones relativas a los arts. 39.2 y $41 \mathrm{CE}$ en la queja formulada al amparo del art. $14 \mathrm{CE}$ ». En el mismo sentido se pronuncia la STC 9/2010.

18 El carácter riguroso con el TC ha examinado los casos de prohibición de discriminación por razón de nacimiento en relación con el art. 39.2 CE ha sido puesto de manifiesto por la doctrina constitucionalista. Vid, entre otros, PÉREZ ROYO, J. «Igualdad», en ARAGÓN GERYES, M. (dir.), Derechos Fundamentales y su protección. Temas básicos de Derecho Constitucional, t. III, Cizur Menor (Thomson Reuters-Civitas), 2011, p. 137. 
de cualquier tipo de filiación, incurre en una discriminación por razón de nacimiento, ya que la filiación no admite categorías jurídicas intermedias ${ }^{19}$.

A la misma conclusión hay que llegar en relación con el art. 39.2 CE en el que se afirma que la ley posibilitará la investigación de la paternidad. Tal como ha señalado Aguado Renedo ${ }^{20}$, la expresión «posibilitará», utilizada en el texto constitucional, indica que el constituyente está generando un verdadero derecho subjetivo que vincula a los poderes públicos, incluido el legislador, y no un simple principio rector ${ }^{21}$. Naturalmente, dicho derecho está sometido a límites tal y como ocurre con el resto de los derechos fundamentales y constitucionales y así ha tenido ocasión de establecerlo el TC en una jurisprudencia reiterada (STC 116/1999, entre otras). No existe en la doctrina acuerdo sobre el alcance de dicho derecho subjetivo. Según algunos autores, la interpretación sistemática de los arts. 39.2 y 39.3 CE es la que desvela el verdadero objeto de dicha norma, que no es otro que servir de instrumento para asegurar los deberes a los que están sometidos los padres para con sus hijos. Desde esta perspectiva, la investigación de la paternidad no es un fin en sí mismo, sino que a través de aquella se trata dar cumplimiento a los deberes a los que alude el art. 39.3 $\mathrm{CE}^{22}$. O, expresado en otros términos, no cabe derivar del art. 39.2 CE un derecho a conocer los orígenes biológicos. Así lo entiende también el TC al destacar que el objetivo de este precepto es el de «constituir, entre los sujetos afectados, un vínculo jurídico comprensivo de derechos y obligaciones recíprocos, integrante de la denominada relación paterno-filial» (STC 116/1999).

Es cierto, no obstante, que en resoluciones más recientes el TC también ha señalado que aunque

«no pueda hablarse de la existencia de un derecho de los progenitores sobre los hijos como correlato de la existencia de los deberes que les impone el art. 39.3 $\mathrm{CE}$, sin embargo, la investigación de la paternidad no puede quedar reducida a un derecho del hijo, con exclusión de toda iniciativa por parte de los progenitores, pues también a éstos alcanza un interés en el conocimiento de la verdad biológica. En este sentido, [...] el mandato del constituyente al legislador de posibilitar la investigación de la paternidad "guarda íntima conexión con la dignidad de la persona (art. 10.1 CE), tanto desde la perspectiva del derecho del hijo a conocer

19 No puede decirse que la STC 67/1998 sea una excepción a esta doctrina. No solo por lo que se desprende de su fallo, sino porque como ha declarado de forma reiterada el TC no existe un derecho fundamental a interesar una sanción penal. En efecto, el tipo penal no podía ser interpretado de forma extensiva so pena de vulnerar el derecho a la legalidad sancionadora del que era titular el progenitor.

20 AGUADO RENEDO, C., «Familia, matrimonio y Constitución Española», cit., p. 81.

21 Vid. AGUADO RENEDO, C., «Familia, matrimonio y Constitución española», cit., pp. 81-82.

22 Vid. en este sentido, entre otros autores, ROCA TRÍAS, E., Familia y cambio social, cit, p. 77; MAGALDI MENDAÑA, N., Derecho a saber, filiación biológica y Administración pública, Madrid (Marcial Pons), 2004, p. 64 . 
su identidad como desde la configuración de la paternidad como una proyección de la persona"» (STC 273/2005) $)^{23}$.

De tal afirmación del TC cabe derivar, en contra de lo que dispone un sector doctrinal, que no hay en la Constitución un derecho fundamental a conocer los orígenes, sino que tal pretensión está ligada con lo que dispone el art. 10.1 CE al afirmar la dignidad de la persona. En todo caso, este giro en la doctrina constitucional, que se manifiesta en relación con el derecho de acceso a la jurisdicción (art. 24.1 CE) bien del padre registral que pretende impugnarla, bien del padre biológico que quiere declararla, ha afectado o, al menos, modulado el entendimiento inicial que del art. 39.2 CE, en cuanto declara que se posibilitará la investigación de la paternidad, se hizo por el TC en los inicios de su andadura. Los votos particulares con los que cuentan las SSTC 138/2005 y 273/2005 así lo ponen de manifiesto.

Más allá del debate acerca de si el conocimiento de los orígenes biológicos constituye un derecho fundamental o no, lo cierto es que la reforma operada en el CC por la Ley 26/2015, de 28 de julio, de modificación del sistema de protección a la infancia y a la adolescencia, lo ha reconocido como derecho lega ${ }^{24}$. Sin duda, esta nueva regulación, resuelve un problema en el que hay varios intereses en juego, por un lado, el derecho de la madre a su intimidad y a mantener el anonimato, y el interés del adoptado a conocer sus orígenes biológicos, que se ha resuelto de forma desigual en países de nuestro entorno y que ha obligado al TEDH a pronunciarse sobre el asunto ${ }^{25}$. En el caso español, es el legislador el que, estableciendo esa ponderación, ha considerado que prevalecen los derechos del adoptado sobre los de los progenitores para lo cual obliga a las entidades públicas, no solo a conservar la identidad de los progenitores durante 50 años, sino también medidas para hacer efectivo el derecho de los adoptados a conocer la identidad de sus progenitores (art. 180 CC).

En mi opinión, el art. 39.3 CE es el que más problemas genera a la hora de estudiar su naturaleza jurídica, ya sea como derecho subjetivo, principio rector o deber fundamental o constitucional. La doctrina ha mantenido posturas dispares en este sentido. Para algunos autores se trata de un verdadero derecho subjetivo de los hijos respecto de los padres a recibir asistencia «de todo orden» ${ }^{26}$. Para este sector doctrinal, el término «deben» referido a los padres, no puede interpretarse sino como un derecho subjetivo en favor de los hijos. Para otros, sin embargo, se trata de un verdadero principio rector que informará la legislación

23 La cursiva es añadida. Llama la atención la afirmación de que una cuestión que está íntimamente ligada a la dignidad humana (art. $10 \mathrm{CE}$ ) no sea considerada un derecho fundamental, sobre todo teniendo en cuenta que el criterio de la dignidad ha sido barajado por el TC para determinar qué derechos fundamentales han de ser reconocidos a los extranjeros (STC 236/2007).

24 Téngase en cuenta que el ejercicio del derecho legal queda condicionado en el caso de los menores de edad a que se ejerza a través de sus representantes legales.

25 Vid., entre otras, STEDH Odièvre c. Francia de 13 de febrero de 2003. Una monografía que contiene interesantes reflexiones sobre los conflictos de intereses que se producen en estos casos es la escrita por MAGALDI MENDAÑA, N. Derecho a saber, filiación biológica y Administración pública, cit.

26 AGUADO RENEDO, C., «Familia Matrimonio y Constitución Española», cit., p. 81. 
positiva, la práctica judicial y la actuación de los poderes públicos, pudiendo ser solamente alegado ante los órganos judiciales por las leyes que los desarrollen ${ }^{27}$. Y, en fin, según Rubio Llorente, el citado deber expresado en el art. 39.3 CE no debe ser considerado entre los deberes constitucionales que, en sentido estricto, se establecen en nuestra Constitución, por lo que no resultan aplicables a este precepto las consecuencias jurídicas que lleva aparejada esta categoría jurídica ${ }^{28}$.

En mi opinión, es francamente difícil derivar del art. 39.3 CE un verdadero derecho subjetivo de los hijos a recibir de los padres «asistencia de todo orden». Los contornos del, en su caso, reconocimiento del derecho subjetivo son tan indeterminados que es difícil delimitar, a partir de supuestos concretos, qué concretas pretensiones son reclamables directamente al juez sin que medie la intervención del legislador. Habrá pretensiones que, sin duda, puedan considerarse insertas en tal precepto, pero en muchos casos no podrá exigirse al órgano judicial determinar los contornos que se derivan de tal obligación constitucionalmente prevista. No puede aducirse de contrario a la idea que se acaba de exponer que los derechos fundamentales también son cláusulas materiales abiertas que requieren respecto a los derechos de configuración legal la intervención del legislador. Tal como ha señalado Rubio Llorente, la diferencia innegable entre los derechos fundamentales y los deberes radica precisamente en que en relación con los derechos puede ser el juez el que, en última instancia, concrete el contenido de los derechos garantizados por la Constitución; sin embargo, en el caso de los deberes, dispone de libertad-aunque no siempre en la misma medida - a la hora de concretar el contenido de estos ${ }^{29}$. Y es que, en mi opinión, el art. 39.3 CE en cuanto establece el deber de los padres de prestar asistencia de todo orden a los hijos está creando un verdadero deber constitucional que genera un mandato a los poderes públicos «para crear deberes individuales desde el respeto a determinados principios, también constitucionales», con el fin de hacer posible la cláusula del Estado social y democrático de Derecho $^{30}$.

27 Vid. en este sentido, entre otros, RODRÍGUEZ GUITIÁN, A. «La reproducción artificial post mortem en España: estudio ante un nuevo dilema jurídico» Revista boliviana de Derecho, vol. 20, 2015, pp. 301 y ss.

28 RUBIO LLORENTE, F. «Los deberes constitucionales», Revista Española de Derecho Constitucional, vol. 62, 2001, p. 19. Según el citado autor, los deberes mencionados en el art. 39 CE (dicho sea en sentido laxo, no con el calificativo de fundamentales) son mencionados explícitamente en la Constitución simplemente como parte de unas instituciones civiles (entre ellas, las relaciones paterno-filiales) respecto de las cuales se hacía necesaria una referencia explícita «para imponer su reconstrucción de acuerdo con los principios constitucionales básicos, en concreto, el de igualdad y el de no discriminación». El término deber constitucional en sentido estricto lo restringe el autor a aquellos deberes que la Constitución impone frente al Estado, no frente a los particulares.

29 RUBIO LLORENTE, F., «Los deberes constitucionales», cit., p. 55.

30 REQUEJO PAGÉS, J.L, «Deberes constitucionales», en MONTOYA MELGAR, A. (dir.), Enciclopedia Jurídica básica, Madrid (Civitas), 1994, p. 1912. Este autor no excluye de la categoría de «deberes constitucionales» a los previstos en el art. 39.3 CE. También considera que dicho precepto impone un verdadero deber a los padres ALÁEZ CORRAL, B., «El ejercicio autónomo de los derechos fundamentales por el menor de edad», cit., p. 74. 
Desde esta perspectiva, los deberes constitucionales, como mandatos al legislador, establecen límites materiales a la acción de todos los poderes públicos incluido el legislador. Me parece que el mandato que establece el art. 39.3 CE, aunque establezca una obligación entre particulares -no entre el individuo y el poder público-, en la medida en la que prevé la consecución de una finalidad prevista en la Constitución -que los padres presten asistencia de todo orden a sus hijos-, está habilitando al legislador para imponer verdaderas obligaciones y deberes a los padres, es decir, restringiendo su autonomía de la voluntad e, incluso, sus derechos fundamentales, sin que esa limitación de su libertad pueda ser cuestionada en la medida en que sirva a la finalidad constitucionalmente impuesta (obviamente, sí puede ser cuestionada por otros motivos: por su carácter desproporcionado, por vulneración del principio de igualdad, etc. $)^{31}$.

En definitiva, el hecho de su naturaleza jurídica de deber constitucional, que en consecuencia impide al juez su concreción sin que medie la interpositio legislatoris, no puede interpretarse en el sentido de que deba ser reconocido como el simple reverso de un derecho subjetivo a favor de los hijos.

Sobre el resto de los apartados del art. 39, esto es, los previstos en los arts. 39.1 y 2, hay acuerdo en la doctrina en cuanto a su carácter de principios rectores.

\section{El artículo 39 CE como conformador de la noción de orden público en las relaciones paterno-filiales: su extensión a todas las ramas del ordenamiento jurídico}

Una vez despejada la naturaleza jurídica de las diversas normas contenidas en el art. $39 \mathrm{CE}$, conviene ahora, aun sin ánimo de exhaustividad, realizar algunas considera-

31 Las reflexiones que se hacen en el texto principal son deudoras de la reflexión de RUBIO LLORENTE,

F. «Los deberes constitucionales», cit., p. 18 y que se transcriben a continuación:

«como es obvio, en efecto, todas las obligaciones, positivas o negativas, que el Derecho nos impone, pueden hacerse derivar de la Constitución, a través de una cadena más o menos larga de mediaciones, una de las cuales, al menos, ha de tener forma de ley. Para ser constitucionalmente válida, la ley, a su vez, solo puede limitar nuestra libertad (nuestros derechos) en cuanto que tal limitación sea necesaria para alcanzar una finalidad amparada por la Constitución (y hacerlo, además, solo en la medida indispensable). La más importante y clara de esas finalidades (en rigor, la única posible para una concepción liberal individualista) es justamente la protección de las libertades garantizadas, de los derechos fundamentales, que no solo imponen al legislador la obligación negativa de respetarlos, sino también la positiva de protegerlos. Cuando la relación entre la protección del derecho y la imposición del deber de hacer o no hacer es inmediata, como sucede, por ejemplo, en el caso de muchas normas penales, el origen constitucional de tal deber es fácilmente discernible, aunque la licitud de la norma pueda ser cuestionada por otras razones (falta de proporción entre el fin y los medios, infracción de la igualdad, etc.). Cuando, por el contrario, la relación entre la finalidad protectora de los derechos y los deberes impuestos por la norma no existe, o solo puede ser establecida a través de una larga serie de mediaciones, la validez constitucional de la norma puede ser cuestionada también en razón del fin perseguido. El enunciado constitucional de deberes sirve para evitar esta puesta en cuestión, o para facilitar la respuesta a la cuestión planteada, en cuanto que habilita directamente al legislador para imponerlos coactivamente». 
ciones en torno a su contenido material que afectan a cómo deben discurrir las relaciones paterno-filiales y a la forma en la que el poder público, en especial, legislador y jueces, quedan vinculados por este precepto. Debido no obstante a que ya se han hecho algunas consideraciones en este sentido respecto a la igualdad de los hijos (naturales o adoptados y matrimoniales o extramatrimoniales) y a la investigación de la paternidad, me centraré ahora en los mandatos de protección propiamente dichos que se formulan como principios rectores y al deber constitucional de que los padres presten asistencia de todo orden a los hijos. Estos forman parte de la noción de orden público constitucional en la materia de la que me ocupo, lo que ha llevado aparejado una importante extensión e impregnación del ordenamiento jurídico entero. Antes de entrar en el estudio de cómo vincula dicho precepto a los jueces y al legislador, conviene hacer algunas precisiones generales en relación con el contenido del art. $39 \mathrm{CE}$.

El dispensar la necesaria protección a los menores de edad es un interés irrenunciable del Estado que, además, se ha elevado al mayor rango al haberse previsto en la norma suprema del ordenamiento jurídico. La familia, en este sentido, cumple un papel fundamental a la hora de llevar a cabo esta finalidad constitucionalmente impuesta. Como agente de bienestar social, es la Constitución la que impone a los padres y a los poderes públicos «la asistencia de todo orden» respecto a los primeros y la «protección integral» respecto de los segundos. Como ha señalado un sector doctrinal, el contenido o las obligaciones concretas que se derivan de tales preceptos no son ni idénticas ni coincidentes ${ }^{32}$, ni tampoco subsidiarias unas de las otras ${ }^{33}$.

De este precepto se deriva también, sin perjuicio de lo que se dirá más adelante, que no es posible observar las relaciones paterno-filiales como simples relaciones horizontales. $\mathrm{La}$ naturaleza de la patria potestad está orientada al cumplimiento de una función constitucional: proteger y procurar atención a los menores de edad, por lo que no cabe traer a colación las distintas tesis -absolutamente contradictorias- que han surgido en la doctrina acerca de la eficacia de los derechos fundamentales en las relaciones entre particulares. Así, los responsables parentales, en virtud de esa atribución constitucional que se enuncia en forma de deber, han pasado a ejercer un poder de naturaleza semipública que se asemeja a una relación de sujeción especial, o como las ha denominado un sector de la doctrina constitucionalista, relaciones privadas de sujeción especial ${ }^{34}$. Esta caracterización, naturalmente, posibilitaría declarar la eficacia de los derechos fundamentales en las relaciones paterno-filiales. Así lo ha establecido el TC en la STC 185/2012 al afirmar que «cuando está en juego el interés de los menores, sus derechos exceden del ámbito estrictamente privado y pasan a tener una consideración más cercana a los elementos de ius cogens que la STC 120/1984, de 10

\footnotetext{
32 En este sentido DÍAZ CREGO, M., «Artículo 39», cit., p. 786.

33 ESPÍN CANOVAS, D., «Artículo 39. Protección de la familia», en ALZAGA VILLAAMIL, Ó. (dir.), Comentarios a la Constitución española de 1978, t. IV, artículos 39 a 55, Madrid (Cortes Generales), 1996, p. 59.

34 Vid., en este sentido, ALAEZ CORRAL, B., «El ejercicio autónomo de los derechos fundamentales por el menor de edad», Revista Europea de Derechos Fundamentales, vol. 21, 2011, pp. 74-76.
} 
de diciembre (FJ 2), reconoce que concurren en los procedimientos judiciales relativos a la familia, a partir de que el art. 39.2 CE sanciona una protección integral de los hijos por parte de los poderes públicos» $\left(\mathrm{F} . J 4^{\circ}\right)$.

Por último, no puede dejar de señalarse que se ha residenciado en este precepto constitucional a través de vía jurisprudencial el principio que se ha convertido en la piedra angular en el tema que me ocupa, que es el del superior interés del menor. El TC ha reiterado en una jurisprudencia ya asentada que dicho principio tiene anclaje constitucional en el art. $39 \mathrm{CE}$, de lo que se derivan importantes consecuencias como se verá a continuación acerca de la actuación de los poderes públicos (SSTC 138/2014)

\section{A. Legislador y artículo $39 \mathrm{CE}$}

Las acciones del legislador tendentes a garantizar la protección de los hijos, como ya se ha dicho, han impregnado el ordenamiento. Así, desde los distintos sectores de este, es posible advertir la actuación del legislador en un doble sentido: bien limitando la autonomía de la voluntad de los padres en las relaciones con sus hijos con el fin de salvaguardar los derechos e intereses de estos, bien reconociendo potestades y concretando los deberes a los titulares de la responsabilidad parental que les permiten cumplir con las obligaciones que constitucionalmente se les imponen. El legislador puede establecer, en consecuencia, no solo potestades o acciones de carácter positivo, es decir, no solo verdaderas obligaciones de hacer o habilitaciones para hacer, sino también implementar prohibiciones que suponen una limitación de la autonomía de la voluntad de estos. Sin ánimo de exhaustividad, ya que sería imposible en este espacio, daré cuenta de algunas de ellas.

Así y por empezar por estas últimas -esto es, las que suponen prohibiciones o limitaciones de la autonomía de la voluntad de los responsables parentales-, se eliminó ya hace más de una década del Código Civil la facultad de corregir a los hijos moderada y razonablemente, lo que cada vez va teniendo repercusiones importantes en el plano penal ${ }^{36}$. Más recientemente, el legislador ha impedido que los cónyuges con hijos menores edad acuerden su separación o divorcio de mutuo acuerdo mediante la formulación de un convenio regulador ante el Letrado de la Administración de Justicia o en escritura pública ante Notario (arts. 82 y $87 \mathrm{CC}$ ). Sin duda, tras esta prohibición se está estableciendo una verdadera reserva de jurisdicción, asegurando además la intervención del Ministerio Fiscal, a favor de los menores en los casos de crisis matrimonial por las implicaciones que esta decisión parental generará en aquellos, lo que redunda en una limitación de la autonomía de la voluntad de los padres. La separación y el divorcio de mutuo acuerdo ante el Letrado de Administración de Justicia o ante Notario sí son posibles cuando los cónyuges tienen hijos mayores

\footnotetext{
35 Sobre el alcance de este principio y su nuevo significado tras la reforma de 2015, me remito al trabajo de SANTOS MORÓN, M.J., «El interés superior del menor. Criterios de determinación y aplicación en casos concretos» publicado en este mismo volumen.

36 Vid. Ley 54/2007, de 28 de diciembre.
} 
de edad o emancipados. En ese caso, aunque no se establece la reserva de jurisdicción, sí se ha previsto por el legislador que «los hijos mayores o menores emancipados deberán otorgar el consentimiento ante el Secretario judicial o Notario respecto de las medidas que les afecten por carecer de ingresos propios y convivir en el domicilio familiar» (art. $82 \mathrm{CC}$ ). La diferencia que se establece entre los hijos menores y mayores de edad en el art. $39.3 \mathrm{CE}$ queda patente en esta regulación. Otras limitaciones de la autonomía de la voluntad de los responsables parentales en relación con los hijos menores de edad se han producido en otros sectores del ordenamiento, como el educativo, en el que entran también en consideración otros principios y bienes dignos de protección constitucional (STC 133/2010) (37. $^{37}$

Por lo que se refiere a las facultades que otorga el legislador a los responsables parentales para que estos puedan cumplir con las obligaciones constitucionalmente impuestas en el art. $39 \mathrm{CE}$, son especialmente destacables las normas del Código Civil contenidas en los arts. 154 y ss. así como aquellas que se contienen en las normas reguladoras del ejercicio de algunos derechos fundamentales y a las que me referiré más adelante.

Esta dimensión constitucional del deber de protección de los niños y de los menores de edad no es algo, sin embargo, exclusivo de la familia o de los que tengan atribuida la patria potestad, sino también de los poderes públicos, ya sean estatales o autonómicos. En efecto, a estos les corresponde asegurar esa protección (art. 39.2 CE) a través de diversas intervenciones. Las funciones que, en este sentido, el legislador impone especialmente a los órganos judiciales (art. 158 CC), al Ministerio Fiscal [art. 3.7 Ley 50/1981, de 30 de diciembre, por la que se regula el Estatuto Orgánico del Ministerio Fiscal, art. 10.2.b) LOPJM, entre otras], la Administración (arts. 172 y ss. CC, arts. 18 y ss. LOPJM, entre otras) y al Defensor Judicial [arts. 163 CC y 10.2.e) LOPJM] resultan decisivos para asegurar la salvaguarda del superior interés del menor ${ }^{38}$. Hay que destacar que las funciones de este último se han visto ampliadas en la reforma que ha tenido lugar en $2015^{39}$.

\section{B. Los órganos judiciales y el art. 39 CE}

Los mandatos de protección previstos en el art. $39 \mathrm{CE}$ han sido tomados en consideración por el TC en conexión con el contenido de algunos derechos fundamentales garanti-

37 Vid. STC 133/2010 a propósito del homeschooling que limita de forma considerable la autonomía de la voluntad de los padres con base en bienes dignos de protección constitucional.

38 Hay que llamar la atención sobre el hecho de que la intervención de los poderes públicos se justifica precisamente por salvaguardar el interés del menor aun en los casos en los que su intervención se produce al supervisar el modo en que los responsables parentales han ejercido sus deberes de protección y cuidado. Vid. en este sentido, AMORES CONRADI, M.A. «Artículo 12», en CASAS BAAMONDE, M.E. y RODRÍGUEZPIÑERO y BRAVO-FERRER, M. (dirs.), Comentarios a la Constitución española. XXX Aniversario, Madrid (Fundación Wolters Kluwer), 2008, p. 224.

39 El art. 2.5.c) LOPJM prevé que en los casos en los que haya discrepancia entre la opinión de los padres, tutores o representantes del menor y el Ministerio Fiscal en el proceso de defensa de los intereses del menor, se nombrará un Defensor Judicial. Se amplían así los casos respecto a la regulación anterior. 
zados en la Sección Primera, del Capítulo Segundo del Título I CE, esto es, de los derechos amparables, lo que ha permitido que el último intérprete de la Constitución haya impuesto obligaciones a los órganos judiciales en relación con la interpretación de la legalidad ordinaria con el fin de dotar de la necesaria protección a aquellos ${ }^{40}$.

Por lo que respecta al plano procesal, son muchas las cuestiones que han permitido al TC referirse a la relación existente entre el art. 39 CE y el derecho a la tutela judicial efectiva sin indefensión (art. 24.1 CE). Sin duda, una de las más importantes es la de exigir un canon de motivación reforzada a aquellas resoluciones judiciales en las que entran en juego los bienes y derechos protegidos por el art. $39 \mathrm{CE}$. La toma en consideración de las circunstancias familiares de las personas, entre otras, debe ser objeto de ponderación por el órgano judicial no solo en los pleitos referidos al Derecho de familia. A partir de estas consideraciones, el TC ha acogido en alguna medida la doctrina del TEDH recaída acerca del derecho a la vida familiar (art. 8.1 CEDH) en torno a los casos de separación de los distintos miembros de la familia -en especial de los menores con sus progenitores-imponiendo a los órganos judiciales este deber de motivación reforzada al que ya se ha hecho referencia al estar en juego no solo los arts. 24.1 y 18.1 CE, sino también el 39 CE (STC 46/2004). Este derecho a la protección de los vínculos entre los distintos miembros de la familia, que generalmente se ven resentidos en el marco de las crisis matrimoniales y por las órdenes de expulsión acordadas en aplicación del Derecho de extranjería, ya había costado al Reino de España alguna condena por parte del TEDH, por lo que debe ser bienvenida esta doctrina del $\mathrm{TC}^{41}$.

También en el plano procesal, hay que destacar las consecuencias interpretativas que se derivan del anclaje constitucional del principio del interés superior del menor, formulado desde 2015 como un derecho legal en el art. 2 LOPJM. Así, en la STC 221/2002 el TC consideró contrario al art. 24.1 CE no dar audiencia a un menor maduro en un asunto que le afectaba ${ }^{42}$. Hay que destacar que en la reforma de LOPJM llevada a cabo en el 2015, el legislador ha incorporado a la ley la doctrina constitucional sobre el derecho de audiencia del

40 Aunque el art. $39 \mathrm{CE}$ no es un precepto amparable, puede ser examinado por el TC en conexión con los derechos fundamentales cuya protección sí puede impetrarse a través del recurso de amparo. Esta posibilidad, que de alguna manera permite al TC «arrastrar» los derechos del Capítulo III al Capítulo II mediante la técnica de los «contenidos conexos» con derechos ubicados en este último Capítulo, no es inhabitual en relación con otros derechos fundamentales.

41 Vid., entre otras, STEDH R.M.S. c. España de 18 de junio de 2013.

42 Aunque el derecho del menor a ser oído estaba ya previsto en la fecha de esta sentencia en el art. 9 LOPJM como un derecho legal, el TC conecta dicho derecho con el art. 24.1 CE con base en que el menor, al tener el juicio y la madurez suficiente, debió haber sido oído por el órgano judicial. Así en el FJ $5^{\circ}$ de la meritada sentencia se establece: «al encontrarnos en este supuesto ante un caso que afectaba a la esfera personal y familiar de una menor, la cual, por la edad que tenía en aquel momento, gozaba ya del juicio suficiente para deber ser oída por la Audiencia Provincial, con el fin de hacer efectivo el derecho a ser oídos que el art. 9 de la Ley de protección jurídica del menor reconoce a los menores en cualquier procedimiento judicial en que estén directamente implicados y que conduzca a una decisión que afecte a su esfera personal, familiar o social (derecho reconocido, además, por el art. 12 de la Convención de las Naciones Unidas sobre los derechos de niño de 20 de noviembre de 1989, ratificada por Instrumento de 30 de noviembre de 1990, expresamente invocada en el art. 3 de la citada Ley Orgánica de protección jurídica del menor), este órgano judicial debió otorgar un 
menor ${ }^{43}$. Y es que, según el TC, el órgano judicial en este tipo de procedimientos en los que está en juego el interés superior del menor no actúa sin más como un órgano que resuelve disputas entre partes, juzgando y haciendo ejecutar lo juzgado, sino que «se amplían las facultades del juez en garantía de los derechos que han de ser tutelados entre los que ocupa un lugar preferente el superior interés del niño» (STC 124/2002). Como consecuencia de lo anterior, los órganos judiciales deben realizar una interpretación flexible y amplia de los supuestos de legitimación en los procesos que versan sobre la declaración de desamparo del menor con el fin de asegurar que aquellos recaban -y verifican- toda la información que resulte precisa para asegurar que la medida adoptada por el juez resultará beneficiosa para el menor (STC 124/2002). Estas obligaciones, que se proyectan sobre el plano procesal y que vienen a clarificar la posición del juez en el proceso, no solo han sido subrayadas por el TC, sino que el TS también ha contribuido a ello. Así, según el TS el «interés del menor» es una cuestión de orden público que faculta al juez a resolver de oficio sin estar sujeto al principio de rogación. A partir de estas consideraciones a propósito del papel atribuido a los órganos judiciales es posible entender la reserva de jurisdicción a favor de los menores a la que antes me referí al dar cuenta de las limitaciones que impone el legislador a la separación y divorcio notarial y ante el Letrado de la Administración de Justicia.

No es solo en el plano procesal o en torno a los derechos del art. 24.1 CE respecto de los que el TC ha extraído consecuencias en orden a realizar una interpretación sistemática de la Constitución por parte de los órganos judiciales y, en consecuencia, a tomar en consideración los principios contenidos en el art. 39.3 CE. Como pone de relieve la STC 26/2001

«el hecho de que los órganos judiciales no se hayan planteado la cuestión de si denegar al trabajador demandante la pretendida asignación del horario nocturno constituía o no un obstáculo para la compatibilidad de su vida familiar y laboral, en atención a las circunstancias concurrentes, supone no valorar adecuadamente la dimensión constitucional ex art. $14 \mathrm{CE}$, en relación con el art. 39.3 CE, del asunto planteado, de suerte que, como hemos afirmado en diversas ocasiones en relación con otros derechos fundamentales, el reproche que desde la perspectiva constitucional merece formularse contra las resoluciones judiciales recurridas en amparo "no es tanto ni solo que haya renunciado a interpretar la normativa aplicable de la manera más favorable a la efectividad del derecho fundamental, sino que ni siquiera haya tenido en cuenta que este derecho estaba en juego y podía quedar afectado" (SSTC 191/1998, de 29 de septiembre, FJ 5; 92/2005, de 18 de abril, FJ 5; y 3/2007, de 15 de enero, FJ 6)».

En el mismo sentido, puede traerse a colación la STC 149/2017.

trámite específico de audiencia a la menor antes de resolver el recurso de apelación interpuesto, por lo que también por este motivo debe apreciarse la vulneración del art. 24.1 CE».

43 Con el fin de que dicha audiencia no tenga un mero carácter formal, el art. 9.3 LOPJM establece que en la resolución sobre el fondo habrá de hacerse constar el resultado de la audiencia al menor, así como su valoración. 


\section{DERECHOS FUNDAMENTALES Y RELACIONES PATERNO-FILIALES}

Como ya se ha puesto de manifiesto en la introducción de este trabajo, la persona es el centro sobre el que pivota la noción de derecho fundamental y de ahí que la familia como tal, como grupo, no sea titular de derechos fundamentales, con la salvedad a la que se hará referencia inmediatamente, por más que así se haya defendido desde determinados postulados doctrinales. Partiendo de esta premisa y de la función que cumple la familia como agente de protección social, en la que se produce además la maduración y la conformación de la personalidad de los menores, tarea en la que no es absolutamente indiferente el Estado $^{44}$, tiene todo el sentido dedicar un epígrafe de este trabajo al estudio de los derechos fundamentales y las relaciones paterno-filiales.

Antes de ello, es preciso hacer algunas aclaraciones acerca del contenido constitucionalmente protegido del derecho a la intimidad familiar (art. 18.1 CE) con el fin de determinar si la familia, como tal, debe considerarse un espacio en el que prime el derecho a la autodeterminación y la autonomía de la voluntad sin que puedan admitirse injerencias de los poderes públicos a la hora de regular las relaciones entre sus miembros. Son dos las cuestiones que, en relación con la familia, han sido examinadas por el TC en conexión con el derecho a la intimidad familiar. En primer lugar y en una jurisprudencia ya consolidada, el TC ha declarado que el derecho a la intimidad no queda circunscrito a la esfera personal, sino que se extiende también a determinados aspectos de otras personas «con las que se guarde una relación personal y estrecha vinculación familiar, aspectos que, por esa relación o vínculo familiar inciden en la propia esfera de la personalidad del individuo que los derechos del art. 18 protegen» (STC 197/1991). Dichas esferas en las que se proyecta el ámbito constitucionalmente protegido del derecho a la intimidad (individual y familiar) están interconectadas con el fin de que el citado derecho despliegue su máxima eficacia. La segunda cuestión con la que el TC ha vinculado el derecho a la intimidad familiar se refiere al mantenimiento de los vínculos familiares, cuestión ya tratada anteriormente, y en la que no queda claro el ámbito protegido por este derecho y el mandato de protección a la familia contenido en el art. 39.1 $\mathrm{CE}^{45}$. Es obvio que ninguna de estas proyecciones del derecho a la intimidad familiar impide que los miembros de la familia sean titulares de derechos fundamentales, no quedando supeditados, en consecuencia, a los intereses familiares.

Una vez aclarado lo anterior, en las siguientes páginas se aborda el estudio de la titularidad y el ejercicio de los derechos fundamentales de los menores de edad, así como las modulaciones o límites, que, como consecuencia de la minoría de los hijos, se imponen al ejercicio de los derechos fundamentales por parte de sus responsables parentales.

\footnotetext{
44 ROCA TRÍAS, E., Familia y cambio social (de la «casa» a la persona), cit., p. 66.

45 Vid., en relación con este asunto, DÍAZ CREGO, M. «Artículo 39», cit., p. 784. Tal y como señala la autora, aunque poco tiene que ver el derecho a la intimidad personal con el mantenimiento de los vínculos familiares frente a decisiones del Estado, el hecho de que el art. 18.1 CE sea objeto de protección en amparo y en cambio no lo sea el art. $39 \mathrm{CE}$, justifica en cierta medida residenciar en aquel precepto el citado derecho.
} 


\section{1. ¿Son titulares de derechos fundamentales los menores de edad?}

La pregunta con la que se enuncia este epígrafe solo puede ser contestada en sentido positivo. Como ha señalado prácticamente de forma unánime la doctrina, aunque en la Constitución se alude al deber de protección de los menores de edad (art. $39 \mathrm{CE}$ ), no hay que sobredimensionar tal mandato ya que cabe deducir de la propia norma fundamental que los menores son también sujetos de derechos y no únicamente meros objetos de protección ${ }^{46}$. Los arts. 10.1 -en cuanto afirma el derecho a la dignidad de la persona y al libre desarrollo de la personalidad, 14- en cuanto ha establecido que el criterio de la edad puede ser un factor de discriminación constitucionalmente proscrita-y el 39.4 - que establece la protección prevista en los acuerdos internacionales para garantizar los derechos de los niños-, todos ellos de la Constitución, son claves para asentar la afirmación de que los menores de edad sí son titulares de derechos fundamentales ${ }^{47}$. Esta tesis ha sido confirmada además por el legislador en la medida en que ha declarado a los menores de edad titulares de derechos legales, considerando en la Exposición de Motivos de la LPJM que «la mejor forma de garantizar social y jurídicamente la protección de la infancia es promover su autonomía como sujeto» ${ }^{48}$. Otra cosa es, naturalmente, que la propia inmadurez del menor le impida ejercer determinados derechos fundamentales en un momento concreto como consecuencia, precisamente, de su inmadurez, por lo que no pueden equipararse a estos efectos capacidad jurídica y capacidad de obrar. Son varias las observaciones que cabe hacer en relación con esta cuestión.

La primera de ellas y la más obvia es que en materia de derechos fundamentales no rigen las reglas generales referidas a la capacidad de obrar. Desde esta perspectiva, podría distinguirse la capacidad de obrar iusfundamental, no coincidente con la capacidad de obrar infraconstitucional ${ }^{49}$. Por lo que se refiere a esta última, el mandato de protección a los menores de edad ha justificado que el legislador restrinja la posibilidad de realizar negocios jurídicos por parte de los menores de edad ${ }^{50}$. El margen de libertad del que dispone el legis-

46 ALÁEZ CORRAL, B., «El ejercicio autónomo de los derechos fundamentales por el menor de edad», Revista Europea de Derechos Fundamentales, vol. 21, 2013, pp. 40-41.

47 ALÁEZ CORRAL, B., «El ejercicio de los derechos fundamentales por el menor de edad», cit., pp. 41-42.

48 Como apunta ALÁEZ CORRAL, B., Minoría de edad y derechos fundamentales, Madrid (Tecnos), 2003, pp. 40-41, a pesar de que la aprobación de la Constitución trajo consigo importantes reformas en el CC en torno a la regulación de las relaciones paterno-filiales, estas se centraron sobre todo en acomodarse al mandato de protección contenido en el art. 39 CE más que en abundar en la posición del menor como sujeto de derechos. Según el citado autor, a estos últimos efectos, fue decisiva la aprobación de la LOPJM en la medida en que fue «la primera constancia jurídico-positiva expresa de la consideración del menor como pleno sujeto de derechos fundamentales». La aprobación de esta norma fue decisiva para dar un giro importante en la interpretación de las normas del CC reguladoras de las relaciones paterno-filiales.

49 ALÁEZ DÍAZ, B., «El ejercicio de los derechos fundamentales por el menor de edad», cit., pp. 47-50.

50 Resulta de interés la STC 55/1994 en la que se declara que es conforme a la Constitución que la ley establezca la prohibición de contratar un seguro para el caso de muerte sobre la cabeza de menores de 14 años o incapacitados. 
lador a la hora de establecer límites a la capacidad de obrar de los menores en los distintos ámbitos del Derecho infraconstitucional (civil, laboral, contencioso-administrativa...) le permite no establecer una regulación homogénea para todos los casos en atención a los principios y bienes dignos de protección que entren en juego (seguridad jurídica, protección de los menores de edad, etc.). Este argumento, ya por sí solo, justificaría que no fuera aceptable exigir la plena capacidad de obrar para posibilitar, ya no solo la titularidad, sino también el ejercicio de los derechos fundamentales a los menores. Pero, como se ha visto, hay argumentos de mayor peso y calado, que ponen de relieve que no puede supeditarse el ejercicio de los derechos fundamentales a alcanzar la mayoría de edad. En efecto, el hecho de que la Constitución no contenga una limitación expresa en este sentido, unido a la condición de persona de los menores de edad, a los que sin duda se dirige el contenido del art. $10 \mathrm{CE}$ en cuanto afirma la dignidad de la persona y el libre desarrollo de la personalidad, son argumentos de peso para sostener tal tesis. Esta idea ha sido acogida por el legislador al establecer en el art. 2.1 LOPJM que «las limitaciones a la capacidad de obrar de los menores se interpretarán de forma restrictiva y, en todo caso, siempre en el interés superior del menor». Como ya se ha dicho, el interés superior del menor debe ser absolutamente compatible con el reconocimiento de una capacidad de obrar iusfundamental que le permita, de forma progresiva, ir desarrollando su personalidad y, en este proceso, es obvio que el ejercicio de los derechos fundamentales, resulta inexcusable. O, en palabras de Aláez Corral, es necesario buscar un equilibrio entre la auto y heteroprotección del menor ${ }^{51}$.

La segunda de las reflexiones que procede hacer y que, sin duda, es bastante más compleja y relacionada con lo anterior, se refiere a las condiciones que son necesarias para que el menor no solo sea titular de derechos fundamentales, sino que, además, pueda ejercerlos de forma autónoma. Nuestro ordenamiento jurídico ha apostado en términos generales, aunque no sin titubeos como se verá más adelante, por hacer depender el ejercicio de los derechos fundamentales del grado de madurez del menor. O, dicho de otro modo, de que el menor tenga capacidad natural para comprender no solo el acto u omisión que va a llevar a efecto, sino también las consecuencias de tal decisión. Así, con carácter general, el art. 162.1 CC establece que se exceptúan de la representación parental los actos relativos a los derechos de la personalidad que el hijo, de acuerdo con su madurez, pueda ejercitar por sí mismo. O lo que es lo mismo, se ha venido considerando que debe regir el principio pro capacitate, de tal manera que cuanta más madurez tenga el menor más espacio de autonomía debe tener ${ }^{52}$. A pesar de que dicho precepto excluye de la representación parental los derechos fundamentales, esto no ha sido óbice para que dicha cuestión haya sido objeto de debate doctrinal. Así, existen diversidad de criterios doctrinales acerca de es si es posible que los padres ejerzan en representación de los hijos los derechos fundamentales de estos. La doctrina civilista, de forma unánime, considera que los padres no pueden ejercer los

\footnotetext{
51 ALÁEZ CORRAL, B., Minoría de edad y derechos fundamentales, cit., p. 42.

52 Vid. en este sentido VERDERA IZQUIERDO, B., «El interés del menor versus interés familiar e interés particular de los progenitores», en MAYOR DEL HOYO, M.V. (dir.), El nuevo régimen jurídico del menor. La reforma legislativa de 2015, Cizur Menor (Thomson Reuters-Aranzadi), 2017, p. 520.
} 
derechos fundamentales de los hijos a través de la técnica de la representación. Así, cuando los responsables parentales toman decisiones que afectan a los derechos fundamentales de los hijos no hacen otra cosa que cumplir con sus funciones de guarda y custodia, es decir, con sus deberes de protección y cuidado del menor. Desde la doctrina constitucionalista, sin embargo, se ha considerado que sí es posible que los padres actúen en representación de sus hijos en relación con los derechos fundamentales de los primeros con argumentos que tienden a maximizar la eficacia de los derechos fundamentales ${ }^{53}$. En mi opinión, sin embargo, es difícil sostener, a pesar de las ventajas que ofrece desde la perspectiva de la mayor eficacia de los derechos fundamentales, que los responsables parentales puedan representar a los hijos en el ejercicio de los derechos fundamentales de los que son titulares aquellos. Y ello, fundamentalmente por dos razones.

En primer lugar, porque a partir de la teoría de la representación vigente en el Derecho Civil, es francamente difícil sostener que los padres actúan en representación de los hijos en estos supuestos. En efecto, para que exista verdadera representación, la voluntad negocial debe nacer en el representante en el momento en que esta se emite «y es la voluntad propia del representante la que actúa y no la del representado» ${ }^{54}$. Parece difícil aceptar esta tesis en el caso del ejercicio de los derechos fundamentales por la propia naturaleza jurídica de estos. Pero es que, además, el deber de protección de los poderes públicos respecto a los menores de edad, aconseja, en algunos casos, considerar tales actuaciones de los responsables parentales, no como actos de representación, sino como derechos legales de los padres en el ejercicio de sus funciones de guarda y custodia, ya que atribuirles este carácter facilita el control de supervisión de tales actos por parte de los poderes públicos en los casos en los que pueda producirse un conflicto de interese ${ }^{55}$. En este sentido, cabe mencionar que el art. 3.2 de la LO 1/1982, de 5 de mayo, de protección civil del derecho al honor, a la intimidad personal y familiar y a la propia imagen establece que cuando los menores no tengan el grado de madurez suficiente, los que ostenten la representación del menor otorgarán su consentimiento, disponiendo a renglón seguido que este último «estará obligado a poner en conocimiento previo del Ministerio Fiscal el consentimiento proyectado. Si en el plazo de ocho días el Ministerio Fiscal se opusiere, resolverá el Juez». La importancia del alcance de la cesión de los derechos del menor se considera tal que se establece, en último término, una reserva de jurisdicción para los casos en los que el Ministerio Fiscal se oponga a dicho consentimiento. $Y$ es que hay supuestos en los que, aunque en apariencia pueden coincidir los intereses de los padres con los de los hijos, estos pueden diferir de forma considerable.

53 ALÁEZ CORRAL, B., «El ejercicio autónomo de los derechos fundamentales por el menor de edad», cit., pp. 45-46.

${ }^{54}$ DÍEZ-PICAZO Y PONCE DE LEÓN, L., «En torno al concepto jurídico de "representación”», La representación en el Derecho, Anuario de la Facultad de Derecho de la Universidad Autónoma de Madrid, núm. 8, 2005, p. 315 .

55 Téngase en cuenta que en estos casos los responsables parentales deben actuar teniendo presente el interés del hijo y no atendiendo a sus propios intereses, lo que, en ocasiones, puede dar lugar a un conflicto de intereses. 
La previsión general del art. 162.1 CC a propósito de la exclusión de la representación parental del menor maduro en el ejercicio de los derechos fundamentales, previsión de carácter general contenida también en otras normas de carácter sectorial ${ }^{56}$, no ha impedido que el legislador haya tomado también en consideración el criterio de la edad a la hora de determinar cuándo los menores de edad pueden ejercer determinados derechos fundamentales. Esta opción por establecer una edad a partir de la cual se presume que el menor es maduro para tomar decisiones en lugar de verificar si concurre o no es circunstancia en el caso concreto, esto es, la madurez, aunque genera seguridad jurídica, ha sido criticada por un sector doctrinal ${ }^{57}$. Algunos ejemplos en los que el legislador atiende al criterio de la edad, en ocasiones en combinación con el criterio de la suficiente madurez son, entre otros y sin ánimo de exhaustividad, la Ley 41/2002, de 14 de noviembre, básica reguladora de la autonomía del paciente y de derechos y obligaciones en materia de información y documentación clínica ${ }^{58}$, la Ley Orgánica 1/2002, de 22 de marzo, reguladora del Derecho de Asociación ${ }^{59}$, entre otras, prestan también atención a la edad de los menores a la hora de establecer determinadas limitaciones al ejercicio de los derechos fundamentales.

A partir de estas premisas y consideraciones, comparto la tesis de Aláez Corral, respecto a la forma en la que el legislador ha resuelto el problema del ejercicio de los derechos fundamentales por parte de los menores edad ${ }^{60}$. En efecto, en lugar de regular las restricciones al ejercicio de los derechos fundamentales, ha establecido los casos en los que los menores de edad sí pueden ejercerlos, por lo que la regla general que cabe derivar de tal actuación es la contraria a la que debería inferirse de la posición y el significado que se deriva de la teoría general de los derechos fundamentales; es decir, un principio general de no prohibición de su ejercicio.

Obviamente, el hecho de que los menores de edad no solo puedan ser titulares de derechos fundamentales sino también ejercerlos cuando son maduros, no implica que no puedan -y deban- establecerse limitaciones o restricciones a su ejercicio que vendrán motivadas,

56 También atiende al criterio del grado de madurez del menor, sin imponer una determinada edad para prestar consentimiento, el art. 3.1 de la LO 1/1982, de 5 de mayo, de protección civil del derecho al honor, a la intimidad personal y familiar y a la propia imagen.

57 Vid., entre otros, SANTOS MORÓN, M.J., «Menores y derechos de la personalidad», El menor ante el Siglo XXI, Anuario de la Facultad de Derecho de la Universidad Autónoma de Madrid, núm. 15, 2011, pp. 73-74.

58 Con carácter general, la edad para prestar consentimiento de forma autónoma en el ámbito sanitario son 16 años (art. 9). No obstante, tal criterio general tiene varias excepciones, en las que el consentimiento corresponderá al representante legal del menor. Tales supuestos son: cuando el paciente tenga la capacidad modificada judicialmente y así conste en la sentencia; cuando el paciente menor de edad no sea capaz intelectual ni emocionalmente de comprender el alcance de la intervención, aunque en este caso deberá ser escuchada su opinión; cuando se trate de una actuación de grave riesgo para la vida o salud del menor, según el criterio del facultativo. En este último caso también deberá ser oída y tenida en cuenta la opinión del menor.

59 El art. 3 de la citada norma permite constituir asociaciones o formar parte de ellas a «los menores no emancipados de más de catorce años con el consentimiento, documentalmente acreditado, de las personas que deban suplir su capacidad».

60 ALÁEZ CORRAL, B., «El ejercicio de los derechos fundamentales por el menor de edad», cit., p. 60. 
en la mayoría de los casos, por la finalidad de proteger al menor. En estos supuestos y para que dicha limitación sea conforme a la Constitución deberá ser proporcionada; esto es, la medida limitativa deberá ser idónea, necesaria y proporcionada en sentido estricto.

Teniendo en cuenta todo lo que se acaban de exponer, puede observarse que la situación de la infancia y la adolescencia se ha visto profundamente modificada de unos años a esta parte en cuanto a las posibilidades que le brinda el ordenamiento jurídico en orden al ejercicio de los derechos fundamentales. Sin embargo, como se verá a continuación, en dicho proceso no han faltado incoherencias y titubeos por parte de los poderes públicos a la hora de regular esta materia. De ello me ocupo en el epígrafe siguiente.

\section{El carácter permanentemente controvertido del ejercicio de los derechos fundamentales por los menores de edad: una nueva vuelta de tuerca tras la reforma de 2015}

Aunque nadie duda a día de hoy que los menores de edad sí son titulares de derechos fundamentales y que su grado de madurez les permite ejercerlos, se observan en algunos casos importantes incoherencias por parte de los poderes públicos a la hora de establecer el marco regulador de las condiciones para su ejercicio y, además, posiciones doctrinales ciertamente contradictorias. Como se verá, estas incoherencias o titubeos a la hora de regular la materia denotan el carácter tremendamente controvertido del ejercicio de los derechos fundamentales por parte de los menores de edad. Creo que puede afirmarse que es una de las cuestiones especialmente sensibles que, sobre todo en relación con el ejercicio de algunos derechos fundamentales, como por ejemplo con el derecho a la vida, pero no solo, generan importantes desacuerdos. Por ello, aunque se puede afirmar que ha existido un cambio de tendencia importante tras la aprobación de la Constitución en considerar al menor maduro como capaz de ejercer derechos fundamentales, la adopción de determinadas reformas legales pone ciertamente en duda que estemos dispuestos a aceptar que los menores decidan de forma autónoma aun en los casos en los que no hay duda de su madurez o capacidad natural. Sin duda, el mandato de protección previsto en el art. 39 CE y el superior interés del menor juegan también un papel esencial en este sentido. A lo anterior hay que añadir el hecho de que la capacidad de decidir de los menores maduros se proyecta sobre determinadas cuestiones que, afectando o pudiendo afectar al ejercicio de determinados derechos fundamentales, resultan también ciertamente controvertidas. Piénsese, entre muchos otros, en el aborto y la transexualidad. Es obvio que, al problema, en sí mismo complejo, del ejercicio de los derechos fundamentales por parte del menor, se añade el carácter también controvertido del ámbito constitucionalmente protegido de algunos derechos y bienes garantizados en la Constitución.

Por lo que se refiere a las incoherencias en las que han incurrido los poderes públicos, es preciso resaltar que, tras la polémica STC 154/2002, de 18 de julio, la Fiscalía General 
del Estado, en la Circular 1/2012, de 3 de octubre, sobre el tratamiento sustantivo y procesal de los conflictos entre transfusiones de sangre $u$ otras intervenciones médicas sobre menores de edad en caso de grave riesgo, parece que viene, de alguna manera, a contradecir el criterio mantenido por el último y máximo intérprete de la Constitución en la mencionada sentencia dictada por el Pleno ${ }^{61}$. En la STC 154/2002 y siguiendo a Aguado Renedo en este punto, la actitud firme, reiterada y contundente del menor a negarse a recibir una transfusión sanguínea amparado para ello en su derecho a la libertad religiosa, fue la causa del resultado de muerte del menor sin que a sus padres pudiera exigirse una conducta distinta a la que siguieron ${ }^{62}$. O dicho de otro de otro modo, el resultado de muerte hay que atribuirlo en exclusiva al menor que actuó conforme a su derecho a la libertad religiosa sin que fuera exigible a los padres una actuación distinta a la que llevaron a cabo para velar por los intereses del hijo. Así lo consideró de forma unánime el TC, lo que llevó a que se declarara nula la condena penal impuesta a los padres por los órganos judiciales ordinarios. Sin embargo, la Circular emitida por la Fiscalía sostiene que, con independencia de la madurez del menor, el Ministerio Público debe instar la aplicación del tratamiento médico con el fin de intentar salvar la vida del menor.

En consonancia con el caso anterior, en el que a los padres se les exigió responsabilidad penal -luego anulada por la STC 154/2002- por la muerte de su hijo, pero desde otra perspectiva, algunos autores también han señalado como una actitud incoherente del legislador el hecho de que, a pesar de reconocer al menor unas mayores cotas de autonomía en atención a su madurez, se siga reconociendo civilmente responsables a los padres o tutores de los daños que aquellos ocasionen ${ }^{63}$.

Más recientemente, la última reforma de la LOPJM, operada por la LO 8/2015, de 22 de julio, parece confirmar el criterio de la Fiscalía al que antes he aludido en la medida en que el art. 2.2. a) contempla como criterio determinante del interés superior del menor la protección de su vida y su supervivencia. En efecto, parece que dicha norma impone a todos los poderes públicos que debe interesarse la salvaguarda de la vida de los menores de edad y su supervivencia, lo que puede plantear problemas en algunos casos límite ${ }^{64}$ además

${ }^{61}$ Téngase en cuenta que dicha Circular se emite poco más de dos meses después de dictarse la STC 145/2002 y que, además, su rúbrica se refiere a las «transfusiones sanguíneas», además de a otros tratamientos médicos.

62 AGUADO RENEDO, C., y GÓMEZ MONTORO, A.J., «Crónica de jurisprudencia constitucional: las decisiones del Tribunal Constitucional español durante el año 2002», Anuario de Derecho Constitucional y Parlamentario, vol. 15, 2003, pp. 250-251.

63 Vid., entre otros, SANTOS MORÓN, M.J., «Menores y derechos de la personalidad. La autonomía del menor», cit., pp. 90-91.

${ }^{64}$ Solo por poner un ejemplo, conviene traer a colación un caso límite que ocupó el interés de la opinión pública en el Reino Unido y en nuestro país. Se trata del caso de Hannah Jones, una niña británica que había enfermado de leucemia a los 5 años. Como consecuencia del tratamiento contra la leucemia, sufrió una lesión cardiaca que la obligó a pasar por quirófano para ponerle un marcapasos. Cuando contaba con 13 años de edad, el equipo médico le advirtió que la única manera de asegurar su supervivencia pasaba por someterse a un trasplante de corazón ya que este funcionaba solo al 10\%. El equipo médico informó que la intervención 
de contrastar con la solución adoptada en otros países de nuestro entorno, en los que, por cierto, se ha inspirado el legislador español a la hora de aproximarse al concepto de superior interés del menor ${ }^{65}$. A pesar de que, en la tramitación parlamentaria de la ley, ningún grupo parlamentario se opuso o cuestionó tal regla, existen en la doctrina discrepancias importantes en este sentido ${ }^{66}$.

Esta tensión y estos titubeos se han observado también a la hora de regular el papel que juegan los padres o los que ostentan la patria potestad de los menores en relación con el ejercicio de los derechos de la personalidad por parte de estos. La última reforma del art. 162.1 CC da cuenta de ello. Aunque dicho precepto ha venido estableciendo desde el año 1981 que quedan excluidos de la representación parental «los actos relativos a los derechos de la personalidad que el hijo, de acuerdo con su madurez, pueda ejercitar por sí mismo», en la reforma llevada a cabo en el año 2015 se ha añadido a lo anterior la siguiente salvedad: «[n]o obstante, los responsables parentales intervendrán en estos casos en virtud de sus deberes de cuidado y asistencia». Aunque, en mi opinión, la adición de dicha salvedad no debe suponer en sí misma considerada una gran novedad respecto a la situación imperante antes de la reforma ${ }^{67}$, -otra cosa es que la aplicación del precepto a casos concretos dote a dicha norma de nuevos contornos interpretativos-, algunos autores han visto en ella una habilitación, no solo para que los padres deban estar presentes en la toma de decisiones importantes por parte de los menores maduros ${ }^{68}$, sino para limitar considerablemente la

quirúrgica suponía un alto riesgo y además no descartaban que la leucemia no volviera a aparecer. Hannah se opuso al tratamiento al considerar que no se veía con fuerzas para enfrentarse al mismo. Aunque sus padres decidieron apoyarla y secundaron su decisión, los médicos sometieron la misma al control de los poderes públicos. La Oficina de Protección al Paciente, tras entrevistarse con ella, dictaminó en favor de la menor y el hospital retiró la demanda. Meses más tarde Hannah cambió de opinión y decidió aceptar el trasplante. La intervención fue exitosa.

${ }_{65}$ Me estoy refiriendo al caso británico y a la Children Act.

66 OJEDA RIVERO, R., «El rechazo del tratamiento médico por los menores de edad en grave riesgo», Indret. Revista para el análisis del Derecho, vol. 3, 2015, p. 20, afirma que la vida no es lo único valioso que posee el menor. Su preservación no representa siempre, necesariamente, su mejor interés. Para saber qué representa dicho interés debemos tomar en consideración la perspectiva en primera persona que tiene el propio menor de su situación y las razones para actuar que surgen de ella. Cuando desde dicha perspectiva el menor ofrezca razones para rechazar el tratamiento objetivamente válidas, nuestro deber será respetar su voluntad. La opinión del menor no puede ser tachada de irrelevante por el hecho de que su vida esté en juego.

${ }_{67}$ Téngase en cuenta que lo prevé la norma, en términos generales, no altera la regulación de las diferentes regulaciones sectoriales o específicas en las que se procede a concretar aún más las posibilidades de decisión del menor y de los que ejercen la patria potestad. Es más, esta habilitación general a los padres para velar por los intereses de los hijos ya se contenía en otros preceptos del CC que, además, deben ser objeto de interpretación sistemática. Con base en estos argumentos, sostengo en el texto principal que dicha adición, por sí sola, no debe llevar aparejada un cambio sustancial respecto a la situación anterior a la reforma.

68 En este sentido, GARCÍAALGUACIL, M.J., «Injerencia en el ámbito de los derechos de la personalidad del menor tras las leyes del 2015: ¿autonomía o intervención?», en MAYOR DEL HOYO, M.V. (dir.), El nuevo régimen jurídico del menor. La reforma legislativa de 2015, Cizur Menor (Thomson Reuters- Aranzadi), 2017, pp. 549-550 considera que la reforma del art. 162.1 CC así como de la Ley 41/2002, de 14 de noviembre, básica reguladora de la autonomía del paciente y de derechos y obligaciones en materia de información y documentación clínica, todas ellas de 2015, posibilitan que los responsables parentales estén presentes y puedan 
autonomía del menor ${ }^{69}$. En efecto, la introducción de criterios jurídicos indeterminados en el citado precepto como «intervendrán» $\mathrm{y}$ «en virtud de sus deberes de cuidado y asistencia» dejan un amplio margen al intérprete que pueden acabar generando más problemas que los que tratan de evitar, de tal manera que la medida puede llevar a desandar el camino que parece que habíamos emprendido desde que se aprobó la Constitución y hasta las reformas operadas en 2015 mediante la LO 8/2015, de 22 de julio, de modificación del sistema de protección a la infancia y adolescencia y la Ley 26/2015, de 28 de julio, de modificación del sistema de protección a la infancia y adolescencia.

Y es que la reforma del art. 162.1 CC no se realiza de forma aislada, sino que va acompañada de otras medidas que, ya por sí mismas, sí suponen una reducción de la autonomía del menor en el ejercicio de sus derechos fundamentales. Sin duda, las más importantes se proyectan sobre el ámbito sanitario en el que cobran un papel más protagonista en orden a otorgar el consentimiento del menor los responsables parentales. Así, el art. 9 de la Ley 41/2002, de 14 de noviembre, básica reguladora de la autonomía del paciente y de derechos y obligaciones en materia de información y documentación clínica, ha sido objeto de constantes reformas que han ido limitando la capacidad del menor para prestar consentimiento a tratamientos médicos, así como al aborto. Antes de la reforma, el menor emancipado o mayor de 16 años podía prestar por sí mismo el consentimiento a la intervención o tratamiento médico, sin excepción alguna. La misma regla era aplicable cuando el menor, aun siendo menor de 16 pero mayor de 12, se le consideraba suficientemente maduro para prestar consentimiento. En la actualidad, sin embargo y como ya se ha apuntado anteriormente, se han establecido restricciones a la autonomía de la voluntad del menor respecto a la regulación anterior ${ }^{70}$.

En definitiva, las sucesivas reformas que se han llevado a cabo ponen de manifiesto que nos encontramos ante un tema no cerrado en el que los sucesivos cambios legislativos van más en la línea de limitar y condicionar el ejercicio de (algunos) derechos fundamentales por parte de los menores.

\section{La patria potestad como criterio modulador del ejercicio de los derechos fundamentales de los responsables parentales}

Los problemas que genera el binomio relaciones paterno-filiales derechos fundamentales no se circunscriben al ejercicio de los derechos fundamentales por los menores de edad, sino que también inciden en el ejercicio de dichos derechos por parte de los que ostenten la patria potestad.

ejercer sus deberes de velar por los intereses del menor, deberes estos que no podían cumplir con anterioridad a la reforma en la medida en que el ordenamiento jurídico no los tenía en cuenta.

69 GARCÍA ALGUACIL, M.J., «Injerencia en el ámbito de los derechos de la personalidad del menor tras las leyes del 2015: ¿autonomía o intervención?», cit., p. 553-554.

70 Vid. nota 58. 
Efectivamente, el hecho de ejercer la patria potestad, así como las obligaciones constitucionales y legales que derivan de la misma han sido tomadas en consideración como un criterio modulador del ejercicio de los derechos fundamentales de los que son titulares los padres o de quienes ejercen la patria potestad. Los deberes y el mandato de protección integral a los hijos que se deriva del art. $39 \mathrm{CE}$, además de los límites concretos de cada uno de los derechos fundamentales, han sido tomados en consideración por el TC en diversos pronunciamientos en los que se planteaban conflictos entre derechos fundamentales o bienes constitucionalmente protegidos. A esta cuestión se refiere de modo inequívoco la STC 154/2002 cuando se afirma a la hora de acometer el enjuiciamiento del recurso de amparo a

«aspectos peculiares o especiales que singularizan el caso que nos ocupa y que, además, pueden afectar de algún modo al ejercicio, por los ahora recurrentes en amparo - que eran los padres del menor fallecido-, de su derecho a la libertad religiosa y de los deberes dimanantes de su condición de garantes. Así sucede con el hecho de que la persona afectada (afectación hasta el punto de haberse producido su muerte) era un menor cuya edad era la de trece años» ${ }^{71}$.

$Y$ es que, en efecto, en el enjuiciamiento de los supuestos en los que se constata que el ejercicio de los derechos fundamentales de los que son titulares los padres puede afectar o repercutir de forma negativa en el menor de edad, debe prevalecer siempre el interés de este último, incluso en los casos en los que los intereses del menor sean de menor rango que los de los padres. El problema general que ha venido generando esta regla, esto es, el de la primacía del interés del menor, ha estribado fundamentalmente en que se trataba de un concepto jurídico indeterminado pues no estaba definido, ni siquiera en términos amplios, por el legislador. Hay que señalar, no obstante, que tal como ya se ha expuesto, la reforma LPJM por la Ley 15/2015, ha establecido los criterios que sirven para determinar en cada caso concreto dicho interés lo que muy probablemente traerá cambios jurisprudenciales. Me temo, sin embargo, que esta nueva regulación no va a terminar con los problemas que generan estos casos.

En otro orden de consideraciones, cabe también apuntar que la limitación o modulación del ejercicio de los derechos fundamentales por parte de los padres puede venir también dada por los derechos fundamentales de los que son titulares los hijos menores de edad. Así, en la STC 141/2000, el TC sostiene que los derechos fundamentales de los padres pueden quedar limitados por los derechos fundamentales de los que son también titulares los hijos menores de edad. En este caso, más allá de los deberes de protección de los padres respecto de los hijos, los límites o modulaciones del ejercicio de determinados derechos por parte de los padres provienen directamente de los derechos fundamentales de los que son titulares los hijos. En esos supuestos, aunque no fuera de aplicación el criterio del interés superior del menor, los derechos de estos quedarían salvaguardados

\footnotetext{
71 La cursiva es añadida.
} 
por los propios límites a los que están sujetos los derechos fundamentales. O dicho de otro modo, la modulación y limitación del derecho se daría igualmente aunque el sujeto no fuera menor de edad y, en consecuencia, no hubiera que indagarse cual debía ser en el supuesto concreto el interés superior de este ${ }^{72}$.

En todo caso, el interés superior del menor es el que debe primar siempre, siendo exigible al juez que realice una ponderación de todos los derechos y bienes constitucionales en conflictos. En este sentido, hay que tener en cuenta que la LOPJM en su última reforma del año 2015 señala en su art. 2.4 que las decisiones y medidas adoptadas por los poderes públicos en interés superior del menor deberán valorar en todo caso los derechos fundamentales de otras personas que pudieran verse afectados y, entre ellas, están las de sus padres o quienes ostentes la patria potestad.

Esta misma limitación o modulación de los derechos de los padres se produce también en los procesos referidos a las declaraciones de paternidad. Según el TC «no hay duda de que, en los supuestos de filiación, prevalece el interés social y de orden público que subyace en las declaraciones de paternidad, en las que están en juego los derechos de alimentos y sucesorios de los hijos, objeto de especial protección por el art. 39.2 CE, lo que trasciende a los derechos alegados por el individuo afectado» (STC 7/1994). En este tipo de pleitos, no ha sido una excepción la limitación de los derechos fundamentales de aquellos contra los que se dirige la demanda de paternidad, sino también en relación con los que constan en el Registro Civil como padres del menor. En efecto, tal y como ha tenido ocasión de establecer el TS, en este último caso y debido a que puede producirse un conflicto de intereses entre los padres registrales y el interés de los menores, aquellos no pueden representar a los hijos en el procedimiento de filiación ${ }^{73}$.

\section{BIBLIOGRAFÍA}

AGUADO RENERO, C., «Familia, matrimonio y Constitución española», en DÍEZ PICAZO GIMÉNEZ, G. (coord.), Derecho de Familia, Cizur Menor (Thomson Reuters-Civitas), 2012, pp. 77-104.

72 En este caso los derechos en juego son la libertad religiosa del padre y de los hijos menores de edad. El TC establece que «frente a la libertad de creencias de sus progenitores y su derecho a hacer proselitismo de las mismas con sus hijos, se alza como límite, además de la intangibilidad de la integridad moral de estos últimos, aquella misma libertad de creencias que asiste a los menores de edad, manifestada en su derecho a no compartir las convicciones de sus padres o a no sufrir sus actos de proselitismo, o más sencillamente, a mantener creencias diversas a las de sus padres, máxime cuando las de éstos pudieran afectar negativamente a su desarrollo personal».

73 Vid. sobre este asunto VÁZQUEZ PASTOR JIMÉNEZ, L., «Las relaciones paterno-filiales. La patria potestad», cit., p. 1864 . 
AGUADO RENEDO, C. y GÓMEZ MONTORO, A.J. «Crónica de jurisprudencia constitucional: las decisiones del Tribunal Constitucional español durante el año 2002», Anuario de Derecho Constitucional y parlamentario, núm. 15, 2003, pp. 217-262.

ALAEZ CORRAL, B. Minoría de edad y derechos fundamentales, Madrid (Tecnos), 2003.

ALAEZ CORRAL, B. «El ejercicio autónomo de los derechos fundamentales por el menor de edad», Revista Europea de Derechos Fundamentales», vol. 21, 2013, pp. 37-77.

AMORES CONRADI, M.A. "Artículo 12», en CASAS BAAMONDE, M.E. y RODRÍGUEZ-PIÑERO Y BRAVO-FERRER, M. (dirs.), Comentarios a la Constitución española. XXX Aniversario, Madrid (Fundación Wolters Kluwer), 2008, pp. 222-226.

GARCÍA ALGUACIL, M.J., «Injerencia en el ámbito de los derechos de la personalidad del menor tras las leyes del 2015: ¿autonomía o intervención?» en MAYOR DEL HOYO, M.V. (dir.), El nuevo régimen jurídico del menor. La reforma legislativa de 2015, Cizur menor (Thomson Reuters-Aranzadi), 2017, pp. 537-555.

GÓMEZ MONTORO, A., «Titularidad de derechos fundamentales», en ARAGÓN REYES, M. (dir.), Derechos Fundamentales y su protección. Temas básicos de Derecho Constitucional, t. III, Cizur Menor (Civitas), 2011, pp. 42-58.

DÍAZ CREGO, M. «Artículo 39», en PÉREZ TREMPS, P. y SÁINZ ARNÁIZ, A. (dirs.), Comentario a la Constitución Española. Libro-Homenaje a Luis López Guerra. 40 Aniversario 1978-2018, Valencia (Tirant lo Blanch), 2018, pp. 781-791.

DÍEZ-PICAZO Y PONCE DE LEÓN, L., «En torno al concepto jurídico de representación», en DEL ÁGUILA TEJERINA, R. (coord.)., La representación en el Derecho, Anuario de la Facultad de Derecho de la Universidad Autónoma de Madrid, vol. 8, 2004, pp. 311-316.

GREGORACI FERNÁNDEZ, B., «La filiación», en DÍEZ-PICAZO GIMÉNEZ, G. (coord.), Derecho de Familia, Cizur Menor (Thomson Reuters-Civitas), 2012, pp. 1607-1630.

MAGALDI, N., Derecho a saber, filiación biológica y Administración Pública, Madrid (Marcial Pons), 2004.

OJEDA RIVERO, R., «El rechazo del tratamiento médico por los menores de edad en grave riesgo», Indret. Revista para el análisis del Derecho, vol. 3, 2015, pp. 1-39. 
PÉREZ ROYO, J. «Igualdad Derechos Fundamentales y su protección», en ARAGÓN REYES. M. (dir.), Temas básicos de Derecho Constitucional, t. III, Cizur Menor (Thomson Reuters-Civitas), 2011, pp. 133-138.

REQUEJO PAGÉS, J.L., «Deberes constitucionales», en MONTOYA MELGAR, A., (dir.), Enciclopedia Jurídica básica, t. II., Madrid (Civitas), 1994, pp. 1910-1912.

ROCA TRÍAS, E. Familia y cambio social (de la «casa» a la persona), Madrid (Cuadernos Cívitas), 1999.

RODRÍGUEZ GUITIÁN, A. «La reproducción artificial post mortem en España: estudio ante un nuevo dilema jurídico», Revista boliviana de Derecho, vol. 20, 2015, pp. 292-323.

RODRÍGUEZ RUIZ, B., «Matrimonio, género y familia en la Constitución española: trascendiendo la familia nuclear», Revista Española de Derecho Constitucional vol. 91, 2011, pp. 69-102.

RUBIO LLORENTE, F., «Los deberes constitucionales», Revista Española de Derecho Constitucional, vol. 62, 2001, pp. 11-56.

SANTOS MORÓN, M. J. «Menores y derechos de la personalidad. La autonomía del menor», El menor ante el Derecho en el Siglo XXI, Anuario de la Facultad de Derecho de la Universidad Autónoma de Madrid, núm. 15, 2011, pp. 63-93.

SANTOS MORÓN, M. J. «El interés superior del menor. Criterios de determinación y aplicación en casos concretos», Revista Jurídica de la Universidad Autónoma de Madrid, núm. 38, 2018, pp. 211-245.

VÁZQUEZ-PASTOR JIMÉNEZ, L. «Las relaciones paterno-filiales. La patria potestad», en DÍEZ-PICAZO GIMÉNEZ, G. (coord.), Derecho de Familia, Cizur Menor (Thomson Reuters-Civitas), 2012, pp. 1807-1900.

VERDERA IZQUIERDO, $\mathrm{B}$, «El interés del menor versus interés familiar e interés particular de los progenitores», en MAYOR DEL HOYO, M.V. (dir), El nuevo régimen jurídico del menor. La reforma legislativa de 2015, Cizur Menor (Thomson Reuters-Aranzadi), 2017, pp. 519-535.

ZAGREBELSKY, G., Principios y votos. El Tribunal Constitucional y la política, trad. Martínez Neira, M., Madrid (Trotta), 2008.SANTOS MORÓN, M. J. «El interés superior del menor. Criterios de determinación y aplicación en casos concretos», Revista Jurídica de la Universidad Autónoma de Madrid, núm. 39, 2018, pp.

VÁZQUEZ-PASTOR JIMÉNEZ, L. «Las relaciones paterno-filiales. La patria potestad», en DÍEZ-PICAZO GIMÉNEZ, G. (coord.), Derecho de Familia, Cizur Menor (Thomson Reuters-Civitas), 2012, pp. 1807-1900. 
VERDERA IZQUIERDO, B, «El interés del menor versus interés familiar e interés particular de los progenitores», en MAYOR DEL HOYO, M.V. (dir), El nuevo régimen jurídico del menor. La reforma legislativa de 2015, Cizur Menor (Thomson Reuters-Aranzadi), 2017, pp. 519-535.

ZAGREBELSKY, G., Principios y votos. El Tribunal Constitucional y la política, trad. Martínez Neira, M., Madrid (Trotta), 2008. 